\title{
The TGF- $\beta$ 1-Induced Expression of Matrix Metalloproteinases in Mesenchymal Stromal Cells is Influenced by Type of Substrate
}

\author{
${ }^{1}$ Center for Regenerative Biology and Medicine (ZRM), University of Tübingen, Germany \\ ${ }^{2}$ Department of Orthopaedic Surgery, University of Tübingen Hospital, Tübingen, Germany \\ ${ }^{3} B G U$ Trauma Center, Tübingen, Germany \\ ${ }^{4}$ Section for Transplantation Immunology, Center for Medical Research, University of Tübingen, Germany \\ ${ }^{5}$ Department of Anesthesiology and Intensive Care, University of Tübingen Hospital, Tübingen, Germany
}

Katrin Warstat ${ }^{1}$, Tino Felka ${ }^{1}$, Falk Mittag ${ }^{2}$, Torsten Kluba ${ }^{2}$, Bernd Rolauffs ${ }^{3}$, Gerd Klein ${ }^{4}$, Melanie L. Hart ${ }^{1,5}$ and Wilhelm K. Aicher $^{1,2 *}$

\begin{abstract}
Transforming growth factor (TGF)- $\beta 1$ activates the expression of matrix metalloproteinases (MMPs) in fibroblasts. Attachment of these cells to laminin-111 further raises the TGF- $\beta 1$-induced expression of MMP-3 and MMP-10. Mesenchymal stromal cells (MSC) attach to a variety of extracellular matrix proteins during development and wound healing. We therefore investigated the TGF- $\beta 1$-regulated expression of MMPs in MSC upon attachment to laminin-111 and type I collagen.
\end{abstract}

The expression of MMPs was determined by quantitative reverse transcription polymerase chain reaction and enzyme-linked immunosorbent assay. The TGF- $\beta 1$ signalling pathways were investigated by immunoblot and by pharmacological blocking of Smad2, MEK/ERK and p38MAPK activities.

Overall, TGF- $\beta 1$ significantly activated the expression of mRNA encoding MMP-3 ( $p \leq 0.05)$, MMP-13 $(p \leq 0.05)$ and TIMP-1 ( $p \leq 0.01)$ in MSC. Induction of MMP-10 was not significant. In contrast to our observation on fibroblasts, the attachment of MSC to laminin-111 did not affect the TGF-B1-induced expression of MMP-3 and MMP-10. Attachment to type I collagen reduced the TGF- $\beta 1$-induced secretion of MMP-3 and MMP-10 compared to cells grown on laminin-111 or tissue culture plastic dishes. The expression of MMP-3 was induced by TGF- $\beta 1$ via Smad2, ERK1/2 and p38MAPK. The expression of MMP-10 was regulated by Smad2 and ERK/1/2, whereas the expression of MMP-13 was shown to be p38 MAPkinase dependent.

We conclude that the regulation of MMP-3, MMP-10, and MMP-13 by TGF- $\beta 1$ proceeds via distinct signalling routes. In contrast to the regulatory pathways in fibroblasts, we could not prove a co-signalling of TGF- $\beta 1$ - and integrin-dependent pathways for the regulation of MMP-3 and MMP-10 in MSC upon attachment to laminin- 111. Therefore, MSC respond differently to TGF- $\beta 1$ and extracellular matrix molecules compared to fibroblasts.

Keywords: Mesenchymal stromal cells; Matrix metalloproteinases; TGF- $\beta$; Integrin signalling; Collagen; Laminin

Abbreviations: Col: Collagen; ERK: Extracellular signalregulated kinases; LN: Laminin; mAb: Monoclonal antibody; MAPK: Mitogen Activates Protein Kinase (=MAP kinase); MMP: Matrixmetalloproteinase; n.s.: not statistically significant; Smad: Homologue of MAD, signaling component; TGF- $\beta$

: transforming growth factor beta; TIMP: Tissue Inhibitor of Matrixmetallo Proteinase

\section{Introduction}

Attachment of synovial fibroblasts to laminin-1 (LM-111) in the presence of TGF- $\beta 1$ induces significant expression and secretion of MMP-3 and MMP-10 [1,2]. Moreover, TGF- $\beta 1$ modulates the expression of integrins on fibroblasts [3] and MSC [4]. We therefore hypothesized that TGF- $\beta 1$-mediated activation of MMP expression in MSC may be modulated by an integrin-dependent signalling pathway not only in synovial fibroblasts but also in MSC.

MSC attach to a variety of extracellular matrix proteins in vitro and in vivo. Long-term bone marrow cultures revealed that marrow stromal cells secrete collagens type I-VI [5-7], as well as laminins LM-411/421 and LM-511/521 [8-10], and thus build up their own microenvironment, also know as niche. Type I collagen (Col-1) is the most abundant protein component of the extracellular matrix in bone and connective tissues. Laminins are a family of glycoproteins mainly located in basement membranes [11]. LM-111 is predominantly expressed during embryonic development [12]. MSC express surface receptors including integrins facilitating their binding to collagens and laminins $[4,13,14]$, and MSC bind to ECM proteins during developmental processes or tissue regeneration.

During wound healing, TGF- $\beta 1$ is secreted in injured tissues $[15,16]$. MSC express the TGF- $\beta$ receptors TGF- $\beta$ RI, -RII and -RIII and are therefore responsive to this cytokine. TGF- $\beta$ further regulates bone formation [17] and causes fibrosis in a variety of tissues [18-20]. These effects are associated with matrix turnover, i.e. the production of extracellular matrix components and induction of matrix degrading enzymes [21].

MMPs are expressed as inactive pre-pro-enzymes. The catalytical

*Corresponding author: Wilhelm K. Aicher, ZMF Research Laboratories, Center for Regenerative Biology and Medicine \& Department of Orthopaedic Surgery University of Tübingen Medical School, Waldhoernle Strasse 22, D 72072 Tübingen, Germany, Tel: x49 70712986045 ; Fax: x49 707129 4637; E-mail: Aicher@uni-tuebingen.de

Received July 06, 2011; Accepted October 27, 2011; Published October 29, 2011

Citation: Warstat K, Felka T, Mittag F, Kluba T, Rolauffs B, et al. (2011) The TGF$\beta 1$-Induced Expression of Matrix Metalloproteinases in Mesenchymal Stromal Cells is Influenced by Type of Substrate. J Tissue Sci Eng 2:108. doi:10.4172/21577552.1000108

Copyright: (C) 2011 Warstat K, et al. This is an open-access article distributed under the terms of the Creative Commons Attribution License, which permits unrestricted use, distribution, and reproduction in any medium, provided the original author and source are credited. 
domain common to all MMPs contains the conserved zinc-binding domain and a unique methionine-turn [22] which play a role in matrix degradation during physiological or pathological processes [22-26]. The stromelysins MMP-3 and MMP-10 degrade a variety of proteins including pro-collagen-I and thus contribute to matrix degradation in bone [27] and cartilage [28]. The collagenase MMP-13 cleaves type II collagen more efficiently than type I or III collagens and is considered to play an important role in physiological and pathological degradation of articular cartilage. The activity of many MMPs is regulated by tissue inhibitors of metalloproteases (TIMPs) [29].

We recently showed that TGF- $\beta 1$ cooperates with integrin signalling upon attachment of synovial fibroblasts to LM-111, significantly boosting the expression of MMP-3 and MMP-10 [1,2] Crosstalk between TGF- $\beta$ and the integrin signalling pathway has been reported in epithelial cells as well [30]. We therefore investigated in this study whether attachment to LM-111 or attachment to another major component of the extracellular matrix, Col-1, affects the expression of MMPs in human TGF- $\beta 1$-activated MSC. In addition, the TGF- $\beta$ signalling pathways were studied by immunoblots and by specific inhibitors blocking the phosphorylation of Smad2, the p38 mitogenactivated protein kinase (MAPK) and extracellular signal-regulated kinases (ERK) $1 / 2$.

\section{Materials and Methods}

\section{Isolation and characterization of MSC}

After written consent, the MSC were isolated by density gradient centrifugation from femoral bone marrow aspirates of patients undergoing endoprosthetic surgery $(n=15)$. The study was approved by the local ethics committee. MSC were grown in MSC Growth Medium (Lonza, Basel, Switzerland) and characterized as described recently [4,31]. Briefly, flow cytometry was performed to confirm the surface expression of CD73 (BD Pharmingen, San Diego, CA, USA), CD90, CD146 (R\&D Systems, Minneapolis, MN, USA) and CD105 (Serotec, Raleigh, NC, USA), as well as lack of CD11b, CD14 (BD Pharmingen), CD34 (Biolegend, San Diego, CA, USA), and CD45 (R\&D Systems) on the cells obtained [31,32]. Further, we proved their ability to differentiate in adipogenic, chondrogenic and osteogenic lineages by established protocols [31,33]. Differentiation of MSC to adipogenic cells was detected by staining the intracellular lipid vesicles with Oil Red-O. The proteoglycans in chondrogenically differentiated pellets were detected by Alcian blue staining. Detection of the mineralized extracellular matrix by von Kossa staining was used to detect osteoblasts after in vitro differentiation of MSC.

\section{Expression of MMPs upon stimulation with TGF- $\beta 1$ and attachment to ECM proteins}

The cells were plated at $5 \times 10^{5} \mathrm{MSC} /$ flasks in tissue culture polystyrene (TCPS) dishes, LM-111-coated dishes (Greiner Bio One (Frickenhausen, Germany), or Col-1-coated dishes (BD Biosciences). After attachment, the cells were stimulated with $10 \mathrm{ng} / \mathrm{mL}$ TGF- $\beta 1$ (Roche, Mannheim, Germany) or left untreated. After $24 \mathrm{~h}$ of incubation, supernatants were collected to investigate the production of MMP-3 (R\&D systems), MMP-10 and MMP-13 (tebu-bio, Offenbach, Germany) by enzyme linked immuno-sorbent assay (ELISA) in a microplate reader (EL800, BioTek, Winooski, VT) according to the guidelines of the suppliers.

The cells were harvested at the same time and RNA was isolated (RNeasy Mini Kit, Qiagen, Hilden, Germany). Reverse transcription of RNA was carried out employing the RT-for-PCR kit
(Clontech, Mountain View, CA, USA). Transcript levels of MMP$1,-2,-3,-9,-13$ and TIMP-1, -2 and -3 were measured after reverse transcription by quantitative polymerase chain reaction (qRTPCR) using commercially available primers (Search LC, Heidelberg, Germany). For MMP-10 the following reagents were used: forward primer: 5'-GGCTCTTTCACTCAGCCAAC-3', reverse primer: 5'-TCCCGAAGGAACAGATTTTG-3', product size: $175 \mathrm{bp}$, access number NM_002425.1). The amplification of cDNA was performed in 35 cycles (LightCycler 1.5, Roche, Mannheim, Germany). Following one initial cycle $\left(95^{\circ} \mathrm{C} 10 \mathrm{sec}, 68^{\circ} \mathrm{C} 10 \mathrm{sec}, 72^{\circ} \mathrm{C} 16 \mathrm{sec}\right.$, temperature transition rate $20^{\circ} \mathrm{C} \mathrm{sec}$ ) the annealing temperature was dropped to $58^{\circ} \mathrm{C}$ with a step size of $0.5^{\circ} \mathrm{C}$. PCR amplification was evaluated by the "fit-points" method [34]. The data represent the mean mRNA expression levels of MMP and TIMP normalized to the expression levels of the housekeeping gene GAPDH. Known amounts of a recombinant standard DNA were used to calibrate each run. The quality of amplification was investigated by melting point analysis $\left(95^{\circ} \mathrm{C}, 58^{\circ} \mathrm{C} 10 \mathrm{~s}, 95^{\circ} \mathrm{C}\right)$. The PCR products were then separated by electrophoresis on $1.5 \%$ agarose gels and visualized by UV-activated ethidium-bromide fluorescence to confirm the expected size.

\section{TGF- $\beta$ signalling pathway}

MSC incubated in TCPS flasks over night in complete medium were activated by addition of $10 \mu \mathrm{g} / \mathrm{mL}$ of TGF- $\beta 1$ for 30,60 , or 120 minutes, harvested, lysed and the protein extracts were separated by SDS-PAGE as described [3]. Untreated cells served as controls (0). The proteins were transferred to nitrocellulose membranes, blocked and probed overnight at $4^{\circ} \mathrm{C}$ with $\mathrm{mAb}$ specific for phospho-Smad2 (Ser465/467), phospho-ERK1/2 (Thr202/Tyr204), phospho-p38MAPK (Thr180/Tyr182). Detection of total p38MAPK served as the loading control. These mAb's were obtained from Cell Signaling Technology (Beverly, MA). After rinsing of the membrane, binding of the primary antibodies was detected by peroxidase-labelled goat anti-rabbit-IgG antiserum (1:1000, Dianova). The binding of antisera was visualized by enhanced chemoluminescence (ECL, Amersham Biosciences, Freiburg, FRG) and recorded by a luminescence-sensitive CCD camera system (Diana, Raytest Inc. Straubenhardt, FRG).

To investigate the contribution of the signalling pathways on regulation of the MMPs, MSC were grown in TCPS flasks over night and the signalling pathways were blocked by addition of the following inhibitors: $100 \mathrm{nM}$ of TGF- $\beta$ RI kinase inhibitor (ALK5i) which blocks the phosphorylation of Smad2/3, or $20 \mu \mathrm{M}$ of the MEK inhibitor which blocks the phosphorylation of ERK1 and ERK2 (PD 98059), or $20 \mu \mathrm{M}$ of the p38MAPK inhibitor (SB 203580) (all from Calbiochem). After 30 min pre-incubation with these inhibitors, cells were stimulated by addition of $10 \mathrm{ng} / \mathrm{mL}$ TGF- $\beta 1$. Cells activated by TGF- $\beta$ without inhibitors and cells left untreated served as controls. After $24 \mathrm{~h}$, supernatants were collected to perform ELISA assays as described above; and RNA was isolated to perform qRT-PCR to quantify transcript levels of MMP-3, MMP-10 and MMP-13.

\section{Statistical analysis}

The mean values, corresponding standard deviations and statistical significance between groups of data were assessed with a two-sided paired Student's $t$-tests using the GraphPad Prism ${ }^{\circledR}$ software. Probability values (p) equal to or less than $0.05\left(^{*}\right)$ or $0.01\left(^{* *}\right)$ were considered to be statistically significant and marked in the figures accordingly.

\section{Results}

\section{Characterization of isolated MSC}

MSC were characterized by flow cytometry and differentiated as 
described recently [4]. The MSC displayed strong staining for CD73, CD90, CD105 and CD146, and absence or low expression of CD11b, CD14, CD34 and CD45 (see supplement, Figure S1). The MSC showed a fibroblast-like morphology and could be differentiated in vitro into adipogenic, chondrogenic and osteogenic lineages (see supplement, Figure S2)

\section{Effect of TGF- $\beta 1$ on the expression of MMPs and TIMPs}

To study the effect of TGF- $\beta 1$ on the expression of MMPs and TIMPs, MSC were seeded in TCPS dishes and activated by addition of TGF- $\beta 1$. Cells without TGF- $\beta 1$ stimulation served as controls (Figure 1). TGF- $\beta 1$ induced a significant, 3 -fold elevation of MMP-3 mRNA $(\mathrm{p}<0.05, \mathrm{n}=8)$, and a 26.7 -fold increase for MMP-13 $(\mathrm{p}<0.05, \mathrm{n}=9$; Figure 1). The expression of MMP-10 was elevated 3-fold as well (n.s. $\mathrm{n}=8$ ). The expression of TIMP-1 was significantly elevated by TGF- $\beta 1$ (1.8-fold, $\mathrm{p}<0.01, \mathrm{n}=7$ ). For all other factors, including MMP-1, MMP2 , MMP-9, TIMP-2, and TIMP-3, a regulatory effect of TGF- $\beta 1$ was not observed in MSC at the transcript level (Figure 1).

\section{Attachment to extracellular matrix proteins affects the expression of MMPs}

Since the expression of MMP-3 and MMP-13 was significantly enhanced by pre-treatment of MSC with TGF- $\beta 1$, and TGF- $\beta 1$ also resulted in elevated transcript levels of MMP-10, this effect was investigated in more detail in a second series of experiments. Here, the influence of the extracellular matrix proteins Col-1 and LM-111 on TGF- $\beta 1$-dependent MMP regulation was investigated as well. When incubated in normal TCPS cell culture flasks, activation of MSC with TGF- $\beta 1$ induced a solid, 6.7-fold elevation of transcripts encoding MMP-3 (Figure 2A), a 25.1-fold elevation of MMP-10 (Figure 2C) and a 48.2-fold elevation of MMP-13 (Figure 2E; Table 1) encoding mRNA. In MSC attached to Col-1, the addition of TGF- $\beta 1$ induced on transcript levels a comparable elevation of MMP-3 (5.6-fold, Figure 2A), MMP-10 (36-fold, Figure 2C) and MMP-13 expression (83.2-fold, Figure 2E; Table 1). Moreover, in MSC attached to LM-111, TGF- $\beta 1$ induced significant elevations in the expression of MMP-3 (5.7-fold,

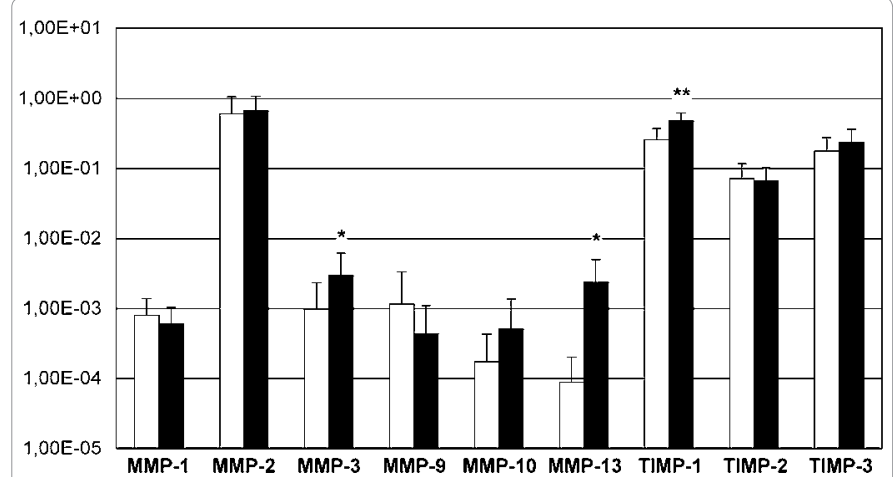

Figure 1: TGF- $\beta 1$-regulated transcript levels of MMPs and TIMPs. MSC were stimulated by TGF- $\beta 1(10 \mathrm{ng} / \mathrm{mL}, 24 \mathrm{~h}$, black bars) or left untreated (white bars). The transcript levels encoding MMPs and TIMPs were measured by qRT-PCR and normalized to the expression levels of GAPDH. Basal expression of MMP-2, TIMP-1, -2 , and -3 was higher compared to the other MMPs. TGF- $\beta 1$ elevated the mRNA expression of MMP-3 ( $<<0.05)$, MMP-13 $(\mathrm{p}<0.05)$, and MMP-10 (n.s.). TIMP-1 transcripts were raised as well $(p<0.01)$, whereas the mRNA levels of MMP-1, MMP-9, TIMP-2, and TIMP-3 either dropped or remained unchanged. The results represent the mean values $\pm S D$ ( $n \geq 7$ donors) of the mRNA transcript levels of the indicated MMPs and TIMPs in MSC. Asterisks indicate significance ${ }^{*}$ $p \leq 0.05 /{ }^{* *} p \leq 0.01$ ) of activated cells vs. controls without TGF- $\beta 1$ stimulation.
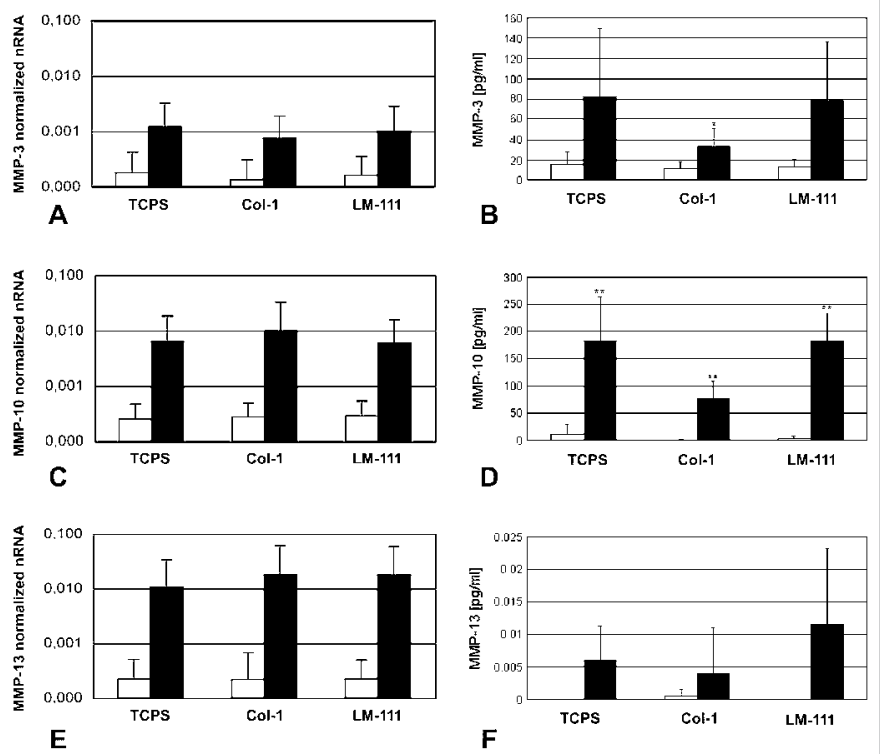

E

$\mathbf{F}$

Figure 2: Modulation of the TGF- $\beta 1$-induced expression of MMPs. The mRNA and protein expression levels of MMP-3 (A, B), MMP-10 (C, D) and MMP-13 (E, F) were measured in MSC grown on different substrates as indicated. Cells were exposed to $10 \mathrm{ng} / \mathrm{mL}$ TGF- $\beta 1$ for $24 \mathrm{~h}$ (black bars) or left untreated as controls (white bars). TGF- $\beta 1$ elevated the expression of MMP-3, MMP-10, and MMP-13 in MSC independently of the substratum on which the cells were grown. The increase in MMP-3 and -10 transcript and protein amounts were lower in MSC incubated on col-1 than in MSC attached to plastic or laminin-111. The expression of MMP-13 was not affected by attachment to collagen. The results are depicted as mean \pm $\mathrm{SD}$ of at least 4 independent experiments. Asterisks indicate significance ${ }^{*}$ $p \leq 0.05 /{ }^{* *} p \leq 0.01$ ) of activated cells vs. controls without TGF- $\beta 1$ stimulation.

\begin{tabular}{|l|l|l|l|}
\hline & MMP-3 & MMP-10 & MMP-13 \\
\hline TCPS & $1.77^{*} 10^{-4}$ & $2.53^{*} 10^{-4}$ & $2.17^{*} 10^{-4}$ \\
\hline TCPS + TGFß & $1.2^{*} 10^{-3}$ & $6.35^{*} 10^{-3}$ & $1.04^{*} 10^{-2}$ \\
\hline induction & 6.7 -fold & 25.1 -fold & 48.2 fold, $\mathrm{p}<0.011$ \\
\hline Col-1 & $1.32^{*} 10^{-4}$ & $2.75^{*} 10^{-4}$ & $2.13^{*} 10^{-4}$ \\
\hline Col-1 + TGFß & $7.41^{* *} 10^{-4}$ & $9.89^{*} 10^{-3}$ & $1.77^{*} 10^{-2}$ \\
\hline induction & 5.6 -fold & 36.0 -fold & 83.2 -fold, $\mathrm{p}<0.03$ \\
\hline LM-111 & $1.78^{*} 10^{-4}$ & $2.68^{*} 10^{-4}$ & $2.2^{*} 10^{-4}$ \\
\hline LM-111 + TGFß & $1.1^{*} 10^{-3}$ & $5.84^{*} 10^{-3}$ & $1.77^{*} 10^{-2}$ \\
\hline induction & 5.7 -fold, $\mathrm{p}<0.028$ & 20.4 -fold, $\mathrm{p}<0.026$ & 80.5 -fold, $\mathrm{p}<0.04$ \\
\hline
\end{tabular}

Table 1: Mean of normalized steady state transcript levels of MMP-3, MMP-10, and MMP13 in MSC (cells from nine donors each) grown in tissue culture polystyrene dishes (TCPS), or in dishes coated with type I collagen (Col-1) or laminin-111 (LM111).

$\mathrm{p}<0.05)$, MMP-10 (20.4-fold, $\mathrm{p}<0.05$ ) and MMP-13 (80.5-fold, $\mathrm{p}<0.05$; Figure 2, Table 1). But in contrast to our results on synovial fibroblasts $[1,2]$, attachment of MSC to Col-1 or LM-111 did not elevate the TGF$\beta 1$-activated expression of MMP-3 or MMP-10 beyond the expression levels recorded in TGF- $\beta 1$ stimulated MSC grown in TCPS flasks (Figure 2A, 2C, 2E).

To investigate the expression of the MMPs on the protein level, supernatants of MSC were collected and tested by ELISA. The secretion of MMP-3 was enhanced by TGF- $\beta 1$ approximately fivefold above controls (n.s., $n=5$, Figure $2 B$ ), and that of MMP- 10 fifteen-fold above controls $(p<0.01, n=5$, Figure 2D). The basal MMP-13 protein levels were below the detection limit. However, TGF- $\beta 1$ stimulated the secretion of MMP-13 in MSC (Figure 2F).

Attachment of MSC to Col-1 in absence of TGF- $\beta 1$ did not 

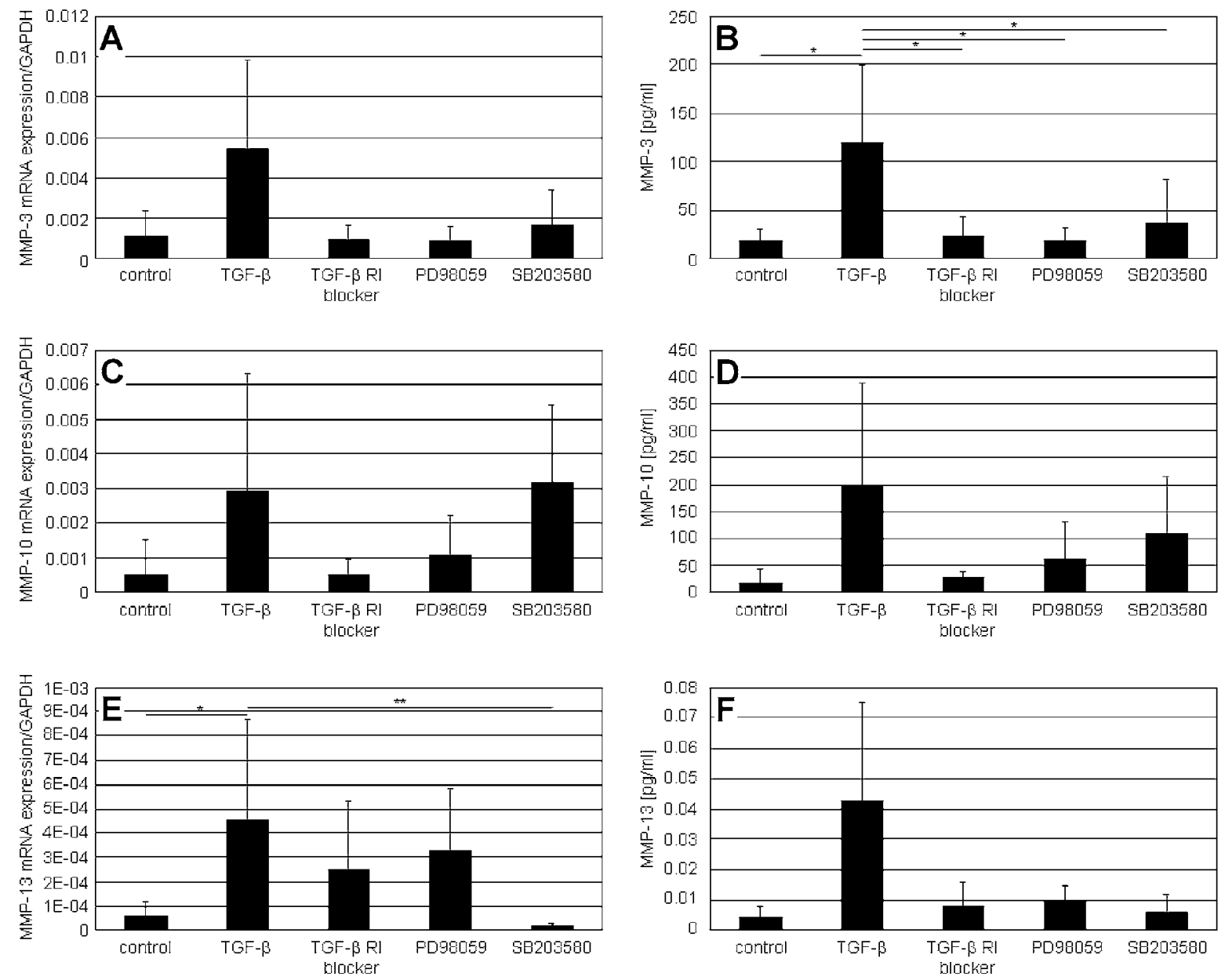

Figure 2: Modulation of the TGF- $\beta 1$-induced expression of MMPs. The mRNA and protein expression levels of MMP-3 (A, B), MMP-10 (C, D) and MMP-13 (E, F) were measured in MSC grown on different substrates as indicated. Cells were exposed to $10 \mathrm{ng} / \mathrm{mL}$ TGF- $\beta 1$ for $24 \mathrm{~h}$ (black bars) or left untreated as controls (white bars). TGF- $\beta 1$ elevated the expression of MMP-3, MMP-10, and MMP-13 in MSC independently of the substratum on which the cells were grown. The increase in MMP-3 and -10 transcript and protein amounts were lower in MSC incubated on col-1 than in MSC attached to plastic or laminin-111. The expression of MMP-13 was not affected by attachment to collagen. The results are depicted as mean \pm SD of at least 4 independent experiments. Asterisks indicate significance ( ${ }^{*} \leq 0.05$ ${ }^{* *} \mathrm{p} \leq 0.01$ ) of activated cells vs. controls without TGF- $\beta 1$ stimulation.

significantly alter the MMP-3 secretion in comparison to that in TCPS adherent MSC $(11.5 \mathrm{pg} / \mathrm{mL} \pm 6)$. But when exposed to TGF- $\beta 1$, MSC growing on Col-1 produced less than half of MMP-3 $(34.4 \mathrm{pg} / \mathrm{mL} \pm$ $17, \mathrm{n}=5)$ compared to TGF- $\beta 1$ activated MSC on TCPS $(82.5 \mathrm{pg} / \mathrm{mL} \pm$ $66, n=5)$. The difference in production of MMP- 3 by TGF- $\beta 1$-activated MCS on TCPS versus Col-1 did not reach significance. The attachment of MSC to LM-111 did not affect their TGF- $\beta 1$-induced expression of MMP-3 (77.8 pg/mL $\pm 58, \mathrm{n}=5)$ compared to cells on TCPS (Figure 2B).

Similar results were obtained for MMP-10. TGF- $\beta 1$ elevated the secretion of MMP-10 in MSC on TCPS $(183.2 \mathrm{pg} / \mathrm{mL} \pm 79, \mathrm{p}<0.01$, $\mathrm{n}=5)$, as well as on LM-111 (183.2 pg/mL $\pm 51, \mathrm{n}=5$, Figure $2 \mathrm{D})$. Note that the MMP-10 secretion from TGF- 31 activated MSC grown on Col-1 $(76.3 \mathrm{pg} / \mathrm{mL} \pm 32, \mathrm{p}<0.01, \mathrm{n}=5)$ remained 2.4 fold below the production measured in supernatants of MSC incubated on plastic or LM-111. Again, the difference in production of MMP-10 by TGF$\beta 1$-activated MCS on TCPS versus Col-1 did not reach significance. Spontaneous secretion of MMP-13 was at or below detection levels. TGF- $\beta 1$ stimulated the production of MMP-13 in MSC attached to
TCPS, Col-1 and LM-111. The attachment on Col-1 had no effect on the secretion of MMP-13, but cellular contact to LM-111 augmented the release of MMP-13 to some extent (Figure 2F). The expression of MMP-1, MMP-2 and MMP-9 and of TIMP-1, -2 and -3 was not affected by the attachment of the cells to Col-1 or LM-111 (data not shown).

\section{TGF- $\beta 1$ signalling pathway}

In order to better understand the TGF $\beta 1$-regulated expression of the MMPs in MSC, we investigated signal transduction by Smad2, ERK- and p38MAPK, (see supplement, Figure S3), and tracked the cell signalling pathways (Figure 3).

Activation of Smad2 as visualized by phosphorylation of the protein was recorded 30 to 120 minutes after addition of TGF- $\beta 1$, peaking one hour after induction. Prior to addition of TGF- $\beta 1$, phosphorylated Smad2 was not detected in MSC (see supplement, Figure S3). Phosphorylation of the $43 \mathrm{kDa}$ ERK1 was slightly raised, again peaking after 60 minutes of activation, whereas phopshorylation of the $41 \mathrm{kDa}$ ERK2 was more prominent. A strong increase in signals 
indicating phosphorylation of p38 MAPK were not observed in TGF$\beta 1$-induced MSC compared to control cells. Detection of total p38 MAPK protein served as loading control (Figure S3).

The addition of TGF- $\beta 1$ induced the MMP-3 mRNA expression in MSC almost 5-fold. Upon exposure of the MSC to the inhibitors affecting AKL5/Smad2, respectively, MEK/ERK, or p38 MAPkinase, MMP-3 mRNA expression levels returned to background levels (Figure 3A). With these inhibitors the TGF- $\beta 1$ induced MMP-3 protein expression was significantly reduced from $119 \mathrm{pg} / \mathrm{mL}$ to $23.1 \mathrm{pg} / \mathrm{mL}$ (ALK5i/Smad2 inhibitor, $\mathrm{p}<0.05), 18.9 \mathrm{pg} / \mathrm{mL}$ (MEK/ ERK inhibitor, $\mathrm{p}<0.05$ ), and $36.2 \mathrm{pg} / \mathrm{mL}$ (p38 MAPkinase inhibitor, $\mathrm{p}<0.05$ ), respectively, (Figure 3B). Thus, in MSC, TGF- $\beta 1$ regulated the expression of MMP-3 mainly via activation of Smad2, ERK1/2, and p38 MAPK.

TGF- $\beta 1$ elevated the MMP-10 transcript levels more than 5-fold. They were reduced slightly by the AKL5/Smad2 inhibitor and by the MEK/ERK inhibitor PD98059, respectively (Figure 3C). In contrast to regulation of MMP-3, the p38 MAPK inhibitor had no significant effects on the mRNA expression of MMP-10 (Figure 3C). The MMP-10 protein level was elevated from $17.4 \mathrm{pg} / \mathrm{mL}$ to $196 \mathrm{pg} / \mathrm{mL}$ by TGF- $\beta 1$ and was diminished to $28 \mathrm{pg} / \mathrm{mL}$ by addition of the AKL5/Smad2 inhibitor, to $61 \mathrm{pg} / \mathrm{mL}$ by the MEK/ERK inhibitor, and to $109 \mathrm{pg} / \mathrm{mL}$ by the p38 MAPkinase inhibitor (Figure 3D). Thus, in MSC, TGF- $\beta 1$ regulated the expression of MMP-10 mainly via activation of Smad2 and ERK1/2.

In contrast, the TGF- $\beta 1$-induced MMP- 13 mRNA expression could be diminished by addition of the p38 MAPkinase blocker SB 203580. TGF- $\beta 1$ induced the MMP-13 mRNA expression significantly (8-fold, $\mathrm{p}<0.05)$. The addition of the SB203580 reduced the TGF- $\beta 1$-induced expression of MMP-13 significantly to $(\mathrm{p}<0.01)$, whereas the TGF- $\beta R I$ and MEK/ERK inhibitors had only minor and non-significant effects (Figure 3E). Spontaneous release of MMP-13 from MSC was very low in vitro but was elevated more than 10 -fold above the detection limit of the ELISA by TGF- $\beta 1$ (Figure $3 \mathrm{~F}$ ). In the presence of each of the inhibitors interfering with signalling of ALK5/Smad2, MEK/ERK or p38MAPK, the production of MMP-13 was reduced to the detection levels of the assay (Figure 3F). Thus, on the transcript level, TGF- $\beta 1$ appears to regulate the expression of MMP-13 mainly via activation of p38 MAPK, and to a lesser extent through Smad2 and ERK1/2.

\section{Discussion}

TGF- $\beta 1$ significantly stimulated the expression of MMP-3, MMP-10 and MMP-13 in MSC. Similar effects are known to occur in other regenerative cell types. In subepithelial myofibroblasts, the expression of MMP-3 is induced by TGF- $\beta$ during repair processes in the gastrointestinal mucosa [35]. Comparably, in synovial fibroblasts, TGF- $\beta$ regulates the expression of MMP-3 and MMP-10 [2]. MMP3 and MMP-10 were recently detected in endometrial regenerative cells [36], and TGF- $\beta$ regulates the expression of MMP-3, MMP-10 and MMP-13 in keratinocytes during wound healing [37-39]. During chondrogenesis and endochondral ossification, MMP-3 and MMP-13 play an important role in tissue remodelling [25,40,41].

In MSC, an activation of MMP-2 and MT1-MMP was reported after $72 \mathrm{~h}$ of treatment with TGF- $\beta 1$, which caused increased migratory ability of the cells. But no change in the expression of MMP-2, MT1MMP and TIMPs was observed after $24 \mathrm{~h}$ of TGF- $\beta 1$ treatment [42]. With respect to the TIMPs this corroborates our results, and suggests a time-dependent induction of MMP expression by TGF- $\beta 1$. Therefore,
MMP-3, MMP-10 and MMP-13 could be among the first proteases induced by TGF- $\beta 1$, leading to matrix degradation in the MSC niche. Later on, other MMPs, such as MMP-2 and MT1-MMP, could promote migration of the MSC to their target tissue during wound healing.

TGF- $\beta 1$ signalling employs the TGF- $\beta$ receptors TGF- $\beta$ RI and -RII, and the intracellular pathways via Smad2/3, ERK1/2 and p38MAPK. By aid of activation-specific antibodies and by use of specific inhibitors, we could prove that in MSC the expression of MMP-3 is elevated by TGF- $\beta 1$ via all three pathways, Smad2, ERK1/2 and p38MAPK. This has also been seen in synovial fibroblasts $[1,2]$. Thus, the expression of MMP-10 is regulated mainly by Smad2 and ERK1/2 in MSC, and expression of MMP- 13 is regulated in TGF- $\beta 1$ activated MSC foremost via $\mathrm{p} 38 \mathrm{MAPK}$. In chondrocytes IL-1 $\beta$ activates the expression of MMP-13 in the same manner [43].

Furthermore, the regulation of MMPs also depends on the substratum to which the cells attach [44-47]. The expression of MMP3 and MMP-10 is not affected by the attachment of MSC to LM-111. But release of MMP-13 is elevated when MSC adhere to LM-111. In contrast, when MSC are grown on Col-1-coated dishes, the TGF- $\beta 1$ induced protein expression of MMP-3 and MMP-10 decreases. The attachment of MSC to Col-1 and LM-111 is amongst others mediated by integrins [13]. Integrin $\alpha 2 \beta 1$ plays a key role in the attachment of MSC to Col-1. The activation of MSC by TGF- $\beta 1$ enhances the binding of MSC to this protein [4]. We assume that integrins not only provide contact points for the attachment of MSC to Col-1 or LM-111, but also influence the TGF- $\beta 1$-induced signalling pathways in these cells.

In contrast to MSC, attachment of synovial fibroblasts to LM-111 modulated the expression of MMP-3 and MMP-10, and the TGF- $\beta 1$ induced expression of MMP-3 and MMP-10 was even enhanced in fibroblasts [1,2]. Activation of osteoblasts by TGF- $\beta 1$ also activated the expression of MMP-3 and MMP-10. As reported in this study for MSC, in osteoblasts the TGF- $\beta$-facilitated expression of MMPs was not enhanced by attachment to LM-111, and was also not ameliorated by attachment to Col-1 (unpublished observation). Differences in expression of integrins or other extracellular matrix binding cell surface proteins between MSC, fibroblasts and osteoblasts may account for the distinct sensitivities of these cells in response to cytokine plus substratum-dependent cell activation.

Crosstalk between cell-matrix attachment and cytokine- or growth factor-induced signalling is known to occur in many cell types, e.g. in epithelial cells [30], where the "crossing point" between the two signalling pathways is the p38MAPK. A similar crosstalk could exist in MSC, enhancing the expression of MMP-13 upon attachment to LM-111 and exposure to TGF- $\beta 1$. Moreover, a paracrine crosstalk may exist between the MSC themselves, and the individual setup of the experiment may influence the outcome. Therefore the induction index computed for the MMPs in a given sets of experiments (e.g. Figure 1, optimized for mRNA yield) will differ from the results observed in another set of investigations (e.g. Figure 2, optimized for exploring key transcripts and cell supernatants from the same culture).

The co-regulation of MMPs by TGF- $\beta 1$ and integrin receptors may play a role during developmental processes such as osteogenesis, and in the chondrogenic differentiation of MSC. During these processes, a permanent reconstruction of the ECM takes place in the developing tissues. Furthermore, the regulated expression of MMPs in response to a combination of growth factor signalling and integrin-mediated ECM recognition may allow directed migration of MSC from their niches into the target tissue during development or wound healing [42]. 
Citation: Warstat K, Felka T, Mittag F, Kluba T, Rolauffs B, et al. (2011) The TGF- $\beta 1$-Induced Expression of Matrix Metalloproteinases in Mesenchymal Stromal Cells is Influenced by Type of Substrate. J Tissue Sci Eng 2:108. doi:10.4172/2157-7552.1000108

Moreover, modulation of cytokine responses by the composition of biomaterials and scaffolds may also be a useful tool to further improve the outcome of tissue engineering. The cells applied together with such an implant will degrade the scaffold during wound repair. Scaffolds generated from a substratum promoting for instance a mild expression of MMPs at the rim of the implant could facilitate its integration. But controlling the expression of MMPs in a load-bearing zone in the center of the scaffold by e.g. Col-1 could indirectly promote the deposition of an extracellular matrix by lowering the expression of the stromelysins MMP3 and MMP10. This may then accelerate the regeneration of the defect. This, however, must be addressed specifically in a separate study in the future.

\section{Acknowledgements}

We are most thankful to Mrs. Tanja Abruzzese for her excellent technical support, Diane Blaurock, M.A., for her invaluable help in the preparation of this manuscript, and Chaim Goziga for help in preparation of the artwork. This project was supported in part by grants to WKA (DFG Ai16/19; BMBF 313755; and Landesstiftung BW 22-005-2009), by the ZRM of the University of Tübingen, and in part by institutional funding.

\section{References}

1. Hoberg M, Rudert M, Pap T, Klein G, Gay S, et al. (2007) Attachment to laminin-111 facilitates transforming growth factor beta-induced expression of matrix metalloproteinase-3 in synovial fibroblasts. Ann Rheum Dis 66: 446-451.

2. Warstat K, Pap T, Klein G, Gay S, Aicher WK (2008) Co-activation of synovia fibroblasts by laminin-111 and transforming growth factor-beta induces expression of matrix metalloproteinases-3 and -10 independently of nuclear factor-kappaB. Ann Rheum Dis 67: 559-562.

3. Warstat K, Hoberg M, Rudert M, Tsui S, Pap T, et al. (2010) Transforming growth factor beta1 and laminin-111 cooperate in the induction of interleukin-16 expression in synovial fibroblasts from patients with rheumatoid arthritis. Ann of the Rheum Dis 69: 270-275.

4. Warstat K, Meckbach D, Weis-Klemm M, Hack A, Klein G, et al. (2010) TGF-ß enhances the integrin $\alpha 2 \beta 1$-mediated attachment of mesenchymal stem cells to type I collagen. Stem Cells Dev 19: 645- 656.

5. Dexter TM, Spooncer E, Simmons P, Allen TD (1984) Long-term marrow culture: An overview of techniques and experience. Kroc Found Ser 18: 57-96.

6. Chichester CO, Fernandez M, Minguell JJ (1993) Extracellular matrix gene expression by human bone marrow stroma and by marrow fibroblasts. Cell Adhes Commun 1: 93-99.

7. Klein G (1995) The extracellular matrix of the hematopoietic microenvironment Experientia 51: 914-926.

8. Gu YC, Kortesmaa J, Tryggvason K, Persson J, Ekblom P, et al. (2003) Laminin isoform-specific promotion of adhesion and migration of human bone marrow progenitor cells. Blood 101: 877-885.

9. Siler U, Seiffert M, Puch S, Richards A, Torok-Storb B, et al. (2000) Characterization and functional analysis of laminin isoforms in human bone marrow. Blood 96: 4194-4203.

10. Silva WA Jr, Covas DT, Panepucci RA, Proto-Siqueira R, Siufi JL, et al. (2003) The profile of gene expression of human marrow mesenchymal stem cells. Stem Cells 21: 661-669.

11. Hallmann R, Horn N, Selg M, Wendler O, Pausch F, et al. (2005) Expression and function of laminins in the embryonic and mature vasculature. Physiol Rev 85: 979-1000.

12. Scheele S, Nystrom A, Durbeej M, Talts JF, Ekblom M, et al. (2007) Laminin isoforms in development and disease. J Mol Med 85: 825-836.

13. Docheva D, Popov C, Mutschler W, Schieker M (2007) Human mesenchyma stem cells in contact with their environment: Surface characteristics and the integrin system. J Cell Mol Med 11: 21-38.

14. Gronthos S, Simmons PJ, Graves SE, Robey PG (2001) Integrin-mediated interactions between human bone marrow stromal precursor cells and the extracellular matrix. Bone 28: 174-181

15. Roberts AB (1995) Transforming growth factor-beta: Activity and efficacy in animal models of wound healing. Wound Repair Regen 3: 408-418.
16. Roberts AB, Sporn MB (1993) Physiological actions and clinical applications of transforming growth factor-beta (TGF-beta). Growth Factors 8: 1-9.

17. Geiser AG, Zeng QQ, Sato M, Helvering LM, Hirano T, et al. (1998) Decreased bone mass and bone elasticity in mice lacking the transforming growth factorbeta1 gene. Bone 23: 87-93.

18. Broekelmann TJ, Limper AH, Colby TV, McDonald JA (1991) Transforming growth factor beta 1 is present at sites of extracellular matrix gene expression in human pulmonary fibrosis. Proc Natl Acad Sci U S A 88: 6642-6646.

19. Roberts AB, Sporn MB, Assoian RK, Smith JM, Roche NS, et al. (1986) Transforming growth factor type beta: Rapid induction of fibrosis and angiogenesis in vivo and stimulation of collagen formation in vitro. Proc Nat Acad Sci U S A 83: 4167-4171.

20. Shah M, Revis D, Herrick S, Baillie R, Thorgeirson S, et al. (1999) Role of elevated plasma transforming growth factor-beta1 levels in wound healing. Am J Pathol 154: 1115-1124.

21. Varga J, Rosenbloom J, Jimenez SA (1987) Transforming growth factor beta causes a persistent increase in steady-state amounts of type I and type III collagen and fibronectin mRNAs in normal human dermal fibroblasts. Biochem J 247: 597-604.

22. Nagase H, Woessner JF Jr (1999) Matrix metalloproteinases. J Biol Chem 274 21491-21494.

23. Birkedal-Hansen H, Moore WG, Bodden MK, Windsor LJ, Birkedal-Hansen B et al. (1993) Matrix metalloproteinases: A review. Crit Rev Oral Biol Med 4 $197-250$

24. Visse R, Nagase H (2003) Matrix metalloproteinases and tissue inhibitors of metalloproteinases: Structure, function, and biochemistry. Circ Res 92: 827839.

25. Mannello F, Tonti GA, Bagnara GP, Papa S (2006) Role and function of matrix metalloproteinases in the differentiation and biological characterization of mesenchymal stem cells. Stem Cells 24: 475-481.

26. Page-McCaw A, Ewald AJ, Werb Z (2007) Matrix metalloproteinases and the regulation of tissue remodelling. Nat Rev Mol Cell Biol 8: 221-233.

27. Bord S, Horner A, Hembry RM, Compston JE (1998) Stromelysin-1 (MMP-3) and stromelysin-2 (MMP-10) expression in developing human bone: Potentia roles in skeletal development. Bone 23: 7-12.

28. Tolboom TC, Pieterman E, van der Laan WH, Toes RE, Huidekoper AL, et al. (2002) Invasive properties of fibroblast-like synoviocytes: Correlation with growth characteristics and expression of MMP-1, MMP-3, and MMP-10. Ann Rheum Dis 61: 975-980.

29. Wojtowicz-Praga SM, Dickson RB, Hawkins MJ (1997) Matrix metalloproteinase inhibitors. Invest New Drugs 15: 61-75.

30. Bhowmick NA, Zent R, Ghiassi M, McDonnell M, Moses HL (2001) Integrin beta 1 signaling is necessary for transforming growth factor-beta activation of p38MAPK and epithelial plasticity. J Biol Chem 276: 46707-46713.

31. Pilz G, Ulrich C, Abruzzese T, Abele H, Schäfer R, et al. (2011) Human term placenta-derived mesenchymal stromal cells are less prone to osteogenic differentiation than bone marrow-derived mesenchymal stromal cells. Stem Cells Dev 20: 635 - 646

32. Dominici M, Le Blanc K, Mueller I, Slaper-Cortenbach I, Marini F, et al. (2006) Minimal criteria for defining multipotent mesenchymal stromal cells. The international society for cellular therapy position statement. Cytotherapy 8 : 315-317.

33. Felka T, Schäfer R, Schewe B, Benz K, Aicher WK (2009) Hypoxia reduces the inhibitory effect of IL-1beta on chondrogenic differentiation of FCS-free expanded MSC. Osteoarthritis Cartilage 17: 1368-1376.

34. Rasmussen R, Morrison T, Herrmann M, Wittwer C (1998) Quantitative pc by continuous fluorescence monitoring of a double strand dna specific binding dye. Biochemica 2: 8-11.

35. Andoh A, Bamba S, Fujiyama Y, Brittan M, Wright NA (2005) Colonic subepithelial myofibroblasts in mucosal inflammation and repair: Contribution of bone marrow-derived stem cells to the gut regenerative response. Gastroenterol 40: 1089-1099.

36. Meng X, Ichim TE, Zhong J, Rogers A, Yin Z, et al. (2007) Endometrial regenerative cells: A novel stem cell population. J Transl Med 5: 57 
Citation: Warstat K, Felka T, Mittag F, Kluba T, Rolauffs B, et al. (2011) The TGF- $\beta 1$-Induced Expression of Matrix Metalloproteinases in Mesenchymal Stromal Cells is Influenced by Type of Substrate. J Tissue Sci Eng 2:108. doi:10.4172/2157-7552.1000108

Page 7 of 7

37. Rechardt O, Elomaa O, Vaalamo M, Paakkonen K, Jahkola T, et al. (2000) Stromelysin-2 is upregulated during normal wound repair and is induced by cytokines. J Invest Dermatol 115: 778-787.

38. Saarialho-Kere UK, Pentland AP, Birkedal-Hansen H, Parks WC, Welgus HG (1994) Distinct populations of basal keratinocytes express stromelysin-1 and stromelysin-2 in chronic wounds. J Clin Invest 94: 79-88.

39. Johansson N, Westermarck J, Leppa S, Hakkinen L, Koivisto L, et al. (1997) Collagenase 3 (matrix metalloproteinase 13) gene expression by haca keratinocytes is enhanced by tumor necrosis factor alpha and transforming growth factor beta. Cell Growth Differ 8: 243-250.

40. Sekiya I, Vuoristo JT, Larson BL, Prockop DJ (2002) In vitro cartilage formation by human adult stem cells from bone marrow stroma defines the sequence of cellular and molecular events during chondrogenesis. Proc Natl Acad Sci U S A 99: 4397-4402.

41. Ortega N, Behonick DJ, Werb Z (2004) Matrix remodeling during endochondral ossification. Trends Cell Biol 14: 86-93.

42. Ries C, Egea V, Karow M, Kolb H, Jochum M, et al. (2007) MMP-2, MT1-MMP, and TIMP-2 are essential for the invasive capacity of human mesenchymal stem cells: Differential regulation by inflammatory cytokines. Blood 109: 40554063

43. Boileau C, Pelletier JP, Tardif G, Fahmi H, Laufer S, et al. (2005) The regulation of human MMP-13 by licofelone, an inhibitor of cyclo-oxygenases and 5-lipoxygenase, in human osteoarthritic chondrocytes is mediated by the inhibition of the p38 map kinase signalling pathway. Ann Rheum Dis 64: 891 898.

44. Werb Z (1997) ECM and cell surface proteolysis: Regulating cellular ecology. Cell 91: 439-442.

45. Arnold M, Cavalcanti-Adam EA, Glass R, Blummel J, Eck W, et al. (2004) Activation of integrin function by nanopatterned adhesive interfaces. Chemphyschem 5: 383-388.

46. Engler AJ, Sen S, Sweeney HL, Discher DE (2006) Matrix elasticity directs stem cell lineage specification. Cell 126: 677-689.

47. Lisignoli G, Cristino S, Piacentini A, Cavallo C, Caplan Al, et al. (2006) Hyaluronan-based polymer scaffold modulates the expression of inflammatory and degradative factors in mesenchymal stem cells: Involvement of CD44 and CD54. J Cell Physiol 207: 364-373. 